\title{
Fabry Disease Diagnosed Based on the Detection of Urinary Mulberry Bodies
}

\author{
Tomoko Honda ${ }^{1}$, Etsuko Komatsu ${ }^{2}$, Satoshi Furuse ${ }^{1}$ and Naobumi Mise ${ }^{1}$
}

Key words: mulberry bodies, Fabry disease

(Intern Med 55: 2903, 2016)

(DOI: 10.2169/internalmedicine.55.7084)

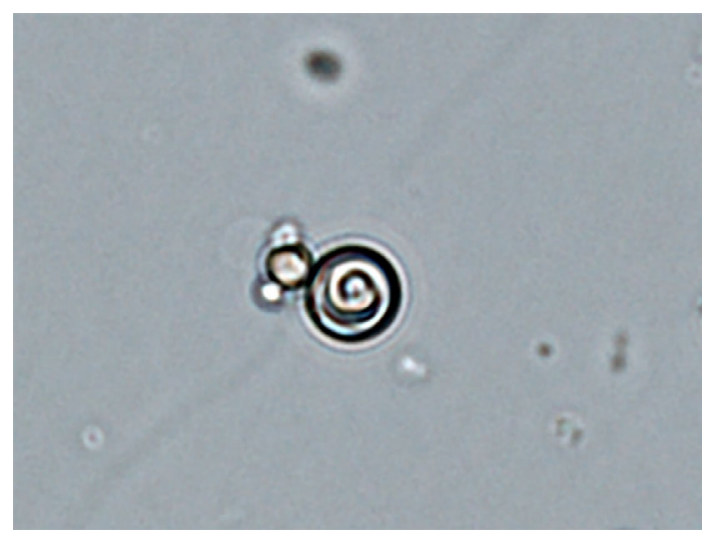

Picture 1.

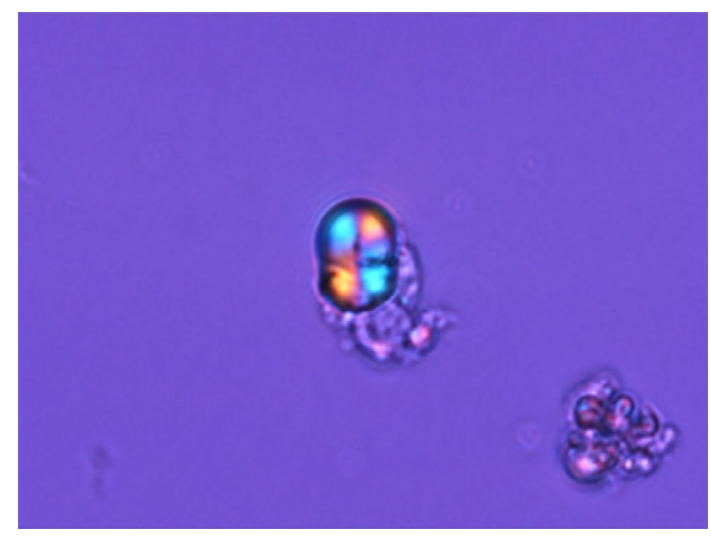

Picture 2.
A 42-year-old Japanese man visited our nephrology department after proteinuria without hematuria was detected in a medical checkup. A physical examination showed no abnormalities. His renal function was normal (serum creatinine concentration: $0.65 \mathrm{mg} / \mathrm{dL}$ ). The urinary analysis at the first visit revealed fat bodies with a whorl-like appearance; socalled mulberry bodies (Picture 1). These bodies showed a characteristic Maltese Cross configuration under polarized light microscopy (Picture 2), which was highly suggestive of Fabry disease (1). Indeed, the alpha-galactosidase (GLA) activity in the patient's white blood cells was as low as 0.1 $\mathrm{nmol} / \mathrm{h} / \mathrm{mg}$ and his serum globotriaosylceramide level was elevated to $69 \mathrm{nmol} / \mathrm{L}$. A genetic analysis revealed a thymine insertion in exon 5 of the GLA-gene, which confirmed the diagnosis of the classic Fabry disease phenotype (2). In a further examination, left ventricular hypertrophy and whorl-like corneal opacity were observed.

In the present case, the detection of mulberry bodies in a microscopic urinalysis was the clue to the diagnosis. Enzyme replacement therapy was initiated four months after the patient's diagnosis.

The authors state that they have no Conflict of Interest (COI).

\section{References}

1. Selvarajah M, Nicholls K, Hewitson TD, Becker GJ. Targeted urine microscopy in Anderson-Fabry Disease: a cheap, sensitive and specific diagnostic technique. Nephrol Dial Transplant 26: 3195-3202, 2011.

2. Rodríguez-Marí A, Coll MJ, Chabás A. Molecular analysis in Fabry disease in Spain: fifteen novel GLA mutations and identification of a homozygous female. Hum Mutat 22: 258, 2003.

The Internal Medicine is an Open Access article distributed under the Creative Commons Attribution-NonCommercial-NoDerivatives 4.0 International License. To view the details of this license, please visit (https://creativecommons.org/licenses/ by-nc-nd/4.0/).

\footnotetext{
${ }^{1}$ Department of Nephrology, Division of Internal Medicine, Mitsui Memorial Hospital, Japan and ${ }^{2}$ Department of Clinical Laboratory, Mitsui Memorial Hospital, Japan

Received for publication January 7, 2016; Accepted for publication January 27, 2016

Correspondence to Dr. Naobumi Mise, misenn@mitsuihosp.or.jp

(C) 2016 The Japanese Society of Internal Medicine Journal Website: http://www.naika.or.jp/imonline/index.html
} 